\title{
Afterword Alibis
}

In the fall of 1987 , an episode of the television series Cagney and Lacey brought the problem of reading and writing about D'Annunzio to prime time. In this episode, the show's "good cops" go undercover in order to expose a crooked game-show host. Dressed as fruits and vegetables, they appear as contestants on the rigged quiz, where they are asked a number of "general knowledge" questions, among them "Who was Italy's first Fascist?" Confident, one of the cops promptly answers: "Benito Mussolini." The buzzer sounds: wrong. Another try: "Gabriele D'Annunzio." Right. If this is "general knowledge" (and has filtered down to American popular culture), it is also perhaps the commonplace that has contributed most to blackening the screen that obscures our reading of D'Annunzio, and it may thus a priori color readings of this book as well. I would like, then, in conclusion, briefly to address this question with an eye to future work.

No rhetorical strategy is in itself either politically progressive or reactionary. In the hands of Baudelaire, Nietzsche, and D'Annunzio, the nineteenth-century rhetoric of sickness opens onto the discovery of the unconscious and the exploration of psychic alterity which underlie the "decentering of the subject"; in the hands of Lombroso, it opens onto twentieth-century theories of racial purity. Degenerates and "degenderates" are equally condemned by fascism and nazism, and "health" reappears as a national, and in the case of nazism, racial ideal. From this point of view, the literary texts I have analyzed can be held to be in the proto-Fascist camp only if all aspects of modern- 
ism itself are held to be proto-Fascist. But at such a level of generality, protofascism no longer has any specificity at all, either ideologically or historically; it becomes merely a term that refers to that which chronologically preceded fascism.

This problem is compounded by the fact that "Fascist ideology" and "Fascist philosophy" have been viewed as oxymorons, as contradictions in terms. ${ }^{1}$ This denial of the existence of a Fascist ideology has roots in the political condemnation of fascism; to recognize an ideology or philosophy in fascism would be to dignify it with an intellectual and theoretical stature it does not merit. And by bringing with it the problem of consent, such recognition would also threaten the notion that fascism was nothing other than state violence imposed upon a fundamentally anti-Fascist people. ${ }^{2}$ The political usefulness (and, at a certain historical moment, perhaps even necessity) of this move is clear: if fascism has no ideology, then it becomes easier to close that particular "parenthesis in history" (as Croce called it), and to consider fascism a historical aberration. Historians have thus often resorted to chronological definitions of fascism itself. Edward Tannenbaum's solution is typical: "The word Fascism with a capital ' $F$ ' refers specifically to the political system of Italy from the early $1920 \mathrm{~s}$ through the early 1940 s and should not be a problem; the problem concerns the word fascism with a small " $\mathrm{f}$." 3 "The "problem" is thus displaced onto "fascism." But if we are to know what is "proto-Fascist" in Italy, we must also know what is Fascist with a capital " $F$," and defining both chronologically empties them of any sense they might have in reference to the ideology of a text: how, indeed, can one look for the ideological roots of something that presumably has no ideology? I should emphasize here that I am speaking of Italian fascism (and of studies of Italian fascism), not of French fascism, where fascism-as-movement never solidified into fascism-as-regime, or of nazism, in which anti-Semitism was a constitutive element.

1. For an excellent discussion of this view, see Pier Giorgio Zunino, L'ideologia del fascismo: Miti, credenze e valori nella stabilizzazione del regime (Bologna: Il Mulino, 1985), especially 11-62.

2. Ibid., 14-24.

3. Edward Tannenbaum, The Fascist Experience: Italian Society and Culture (New York: Basic Books, 1972), 3.

4. Because French fascism never became a regime, it has seemed a particularly "pure" case. Zeev Sternhell writes that "ideologies and movements may be 
Distinctions need to be made, and are made by scholars such as Renzo De Felice, Zeev Sternhell, or George Mosse. ${ }^{5}$ It is not, for example, of small importance that anti-Semitism and racism were not an integral part of Italian fascism, which, as De Felice writes, "adopted them late and largely for reasons of political convenience and to avoid being at odds with other Axis powers." As a result of those distinctions, however, studies of French Fascist ideology or of Nazi ideology cannot automatically be transferred to Italian fascism, and it is only relatively recently, above all with the work of Renzo De Felice, that studies of Italian fascism have begun to allow us to understand the specificity of its ideology. That work of description and analysis of Fascist ideology must be continued not only by historians but also by literary scholars before we can "judge" the culture that produced fascism and the culture that fascism produced.

Indeed, in the absence of an analysis of Fascist ideology, the attribution of protofascism to D'Annunzio has had more to do with retrospective reading than with whatever antidemocratic, antiparliamentary statements we might (and can) isolate in his works. This reading is based on the biographical D'Annunzio, who in 1919 occupied Fiume and as the comandante acquired a political following and stature that for a brief period rivaled Mussolini's. Mussolini himself adopted slogans and certain elements of his political style from D'Annunzio and took it upon himself to ensure D'Annunzio's continued assent, or at least silence, during the regime. ${ }^{7}$ It is from this final period of his

discovered in their purest form" before coming to power and that France therefore "offers especially suitable conditions" for the study of Fascist ideology. See Sternhell, Neither Right nor Left: Fascist Ideology in France, trans. David Maisel (Berkeley: University of California Press, 1986), 1; see also Alice Y. Kaplan, Reproductions of Banal ity: Fascism, Literature, and French Intellectual Life (Minneapolis: University of Minnesota Press, 1986), 51-55.

5. This is not to say that common denominators cannot be found. For concise discussions of the need for such distinction, see Renzo De Felice, Intervista sul fascismo, ed. Michael Ledeen (Bari: Laterza, 1976), and De Felice, Interpretations of Fascism, trans. Barbara Huff Everett (Cambridge: Harvard University Press, 1977), especially the chapter "Fascism as a Problem of Interpretation."

6. De Felice, Interpretations of Fascism, 11.

7. On D'Annunzio in Fiume, see Renzo De Felice, D'Annunzio politico (Bari: Laterza, 1978); De Felice, Sindacalismo rivoluzionario e fumanesimo nel carteggio 
life that D'Annunzio earned the epithet "the John the Baptist" of fascism or, as Michael Ledeen puts it, "the first Duce." From that point, his works will be reread on the assumption that biographical continuity is equal to, indeed causes, an ideological continuity and coherence in an author's texts. But drawing literary conclusions from biographical data, like drawing biographical conclusions from literary data, depends on elision and an ignorance of the rhetorical nature of the literary text. Either tactic may be useful for indicting or absolving authors and their works, but neither helps us to understand the texts in question. I do not mean to indict or to absolve. A reading of D'Annunzio's writings and speeches during the Fiume period does indeed have much to tell us about fascism-as-movement; revolutionary elements still coexist with the reactionary elements that reigned when fascism becames regime. Such a reading will also tell us what Mussolini and fascism could absorb from D'Annunzio and what turned out to be indigestible. ${ }^{8}$ Fascism incorporates

De Ambris-D'Annunzio (1919-1922) (Brescia: Morcelliana, 1966); De Felice, Mussolini il rivoluzionario, 1883-1920 (Turin: Einaudi, 1965); and Michael Ledeen, The First Duce: D'Annunzio at Fiume (Baltimore: Johns Hopkins University Press, 1977).

8. The Fascists themselves were careful to establish a proper distance from D'Annunzio at the same time as they attempted to win over his followers. In the entry "Fascism" in the 1932 Enciclopedia Treccani (the first section of which is signed "Benito Mussolini" but was presumably written by Giovanni Gentile, and the second half of which is signed "Gioacchino Volpe"), a line is carefully drawn between D' Annunzio and Fiume, and Mussolini and fascism. Volpe writes of the November 1921 Congress of Fascists: "For four or five months, there had been a word that agitated souls and created oppositions between the men most representative of fascism, almost between city and city, region and region: the peace treaty. There were the relationships between Fascists and the Legionnaires of Fiume, between fascism and D'Annunzianism, a little bit between Mussolini and D'Annunzio, who watched over his young companions from afar. Not all of 'Fiumeanism' [fiumanesimo] had mixed into fascism. A part of it [Fiumeanism] had become a supporter of the word of Carnaro, almost opposed to the word of fascism. . . . [Mussolini] had words of gratitude for D'Annunzio's work, but excluded the possibility that fascism would find its laws in the statutes of Carnaro: he admitted only that these latter had been animated by a spirit that the Fascists could absorb and make their own." The "word of Carnaro" here refers to the constitution that D'Annunzio and Alceste De Ambris had written for Fiume, the "Carta del Carnaro." Among the words of Carnaro which Mussolini did not make his own was women's suffrage. Enciclopedia italiana, ed. Istituto 
ideologically incompatible elements from diverse literary and philosophical sources and musters considerable rhetorical force to produce a semblance of coherence, but not everything can be incorporated and certainly not D'Annunzio's entire corpus.

I have here attempted to go behind the blackened screen of retrospective reading and to analyze the decadent rhetoric of sickness in the late nineteenth century. This rhetoric of sickness provided the occasion and alibi for an alterity that positivism labeled criminal, that literary critics have found offensive, and that fascism, with its celebration of virility, found indigestible. While this rhetoric may be no alibi for D'Annunzio's later political involvement, it points to a D'Annunzio whose texts are embedded in quite a different context, quite another matrix. If the decadents' "occupation" is dependent on the expulsion of woman from the scene of art, it also refuses the logic of castration which would assign her the place of "have-not" in a world of haves and havenots. Attended by furies, chimeras, androgynes, hermaphrodites, and Medusas, that project is tormented and fraught with contradictions and is part of what Christine Buci-Glucksmann has called "the feminization of culture" in the second half of the nineteenth century and the beginning of the twentieth, "a great labor of deconstruction of the frontier of masculine and feminine identities," a labor in which "the metaphor of the feminine arises as an element of rupture of a certain rationality put into question, of a historical and symbolic continuum, by designating a heterogeneity and a new alterity." The rationality it calls into question is that of positivism and all ideologies of "progress"; the symbolic continuum, that of the figuration of sexual difference. In appropriating

G. Treccani (Milan: Rizzoli, 1932), 14:859. For a discussion of the Fiumean writings, see Barbara Spackman, "'Il verbo (e)sangue': Gabriele D'Annunzio and the Ritualization of Violence," Quaderni d'Italianistica 4.2 (1983): 219-29; and Spackman, "The Fascist Rhetoric of Virility," Stanford Italian Review 8.1-2 (1988): 81-101.

9. Christine Buci-Glucksmann, La raison baroque: De Baudelaire à Benjamin (Paris: Galilée, 1984), 33. I learned of this fine book (whose reading of Baudelaire is complementary to my own) only after completing my manuscript, and am grateful to Linda Bolis for bringing it to my attention. For an extended critique of the appropriation of the position of woman by contemporary "male" theory, see Alice Jardine, Gynesis: Configurations of Woman and Modernity (Ithaca: Cornell University Press, 1985). 
and speaking of, through, and for the otherness of woman's body, these writers place themselves "elsewhere" on the continuum of sexual difference, and sickness provides them with the alibi they need for an alterity that positivism finds criminal. But the expulsion and exclusion of woman from this scene is also the mark of a nonrecognition of the "other"; it is this expulsion that comes back to haunt the text in the form of La Gioconda's stony gaze. The fetishist's disavowal thus can be taken as an alibi in yet another sense: it is the excuse for that nonrecognition, a claim to have been elsewhere than at the scene in which diversity is transformed into difference. It is a precarious position, which, on the one hand, can fall into appropriation and yet, on the other, refuses the opposition that makes such appropriation possible. I hope to have shown not only how these texts fall into appropriation but also how, in their most precarious moments, they potentially resist insertion into the symbolic continuum that has defined woman as man's other. 